Finanse, Rynki Finansowe, Ubezpieczenia nr 4/2016 (82/1)

\title{
Corporate Social Responsibility Reporting in Local Government Units
}

\author{
Magdalena Kowalczyk*
}

\begin{abstract}
Aim - an attempt to present the potential of corporate social responsibility reporting in local government units.

Methodology of the research - The elaboration is based on the methodology of literature research and a case study. In order to present the principles of making corporate social responsibility reports I used fragments of the social responsibility system elaborated by the Office of the Marshal of the Mazowieckie Voivodeship.

Result - On the basis of the conducted research I was able to demonstrate the importance of social responsibility in local government units and indicate its influence on the evaluation of the units' operations.

Originality/value - According to the results of the conducted research, social responsibility reporting in local government units allows for the development of institutional potential and an evaluation of the effectiveness of the units' operations.
\end{abstract}

Keywords: local government units, corporate social responsibility, local government reporting

\section{Introduction}

According to the definition, local government constitutes from the local community residing in the same area. It signifies that the main goal of all the activities undertaken by the local government unit is to improve the effectiveness of its operations measured on the basis of the level of satisfaction of the local community. Due to that, for several years we have been observing significant changes in the management of local government units. The introduction of modern solutions to management is also connected with constant development of the accounting system in local government units. Over the last several years the accounting of local government units has evolved into more commercial solutions, typical for private entities. At present the commercial sector focuses more and more on the reporting of the so-called corporate social responsibility. The European Commission underlined the importance of revealing information on the balanced development by business entities, like the data considering both social and environmental factors. The information is also significant for local government units as the social and environmental aspects are parts of the tasks they perform. That is the reason why currently the importance of social responsibility reporting

\footnotetext{
* dr Magdalena Kowalczyk, Państwowa Wyższa Szkoła Zawodowa w Kaliszu, madlene13@wp.pl.
} 
is emphasized, as it is believed that the content of traditional reports is insufficient to reflect the full view of local government units' operations.

The purpose of the herein study is to demonstrate the potential of social responsibility reporting in local government units. The study consists of 3 parts: the first one presents the significance of financial and budgetary reporting in local government units; the second one concentrates on the core issue of social responsibility in local government units, and the third one illustrates the example of social responsibility reporting in local government units. Local government units are the objects of the herein study and the reporting of corporate social responsibility constitutes its subject matter.

\section{The importance of financial and budgetary reporting in local government units}

Local government units prepare two types of reports:

- budgetary reports,

- financial reports.

Table 1 presents the scope of financial and budgetary reporting in local government units.

\section{Table 1}

Financial and budgetary reporting in local government units

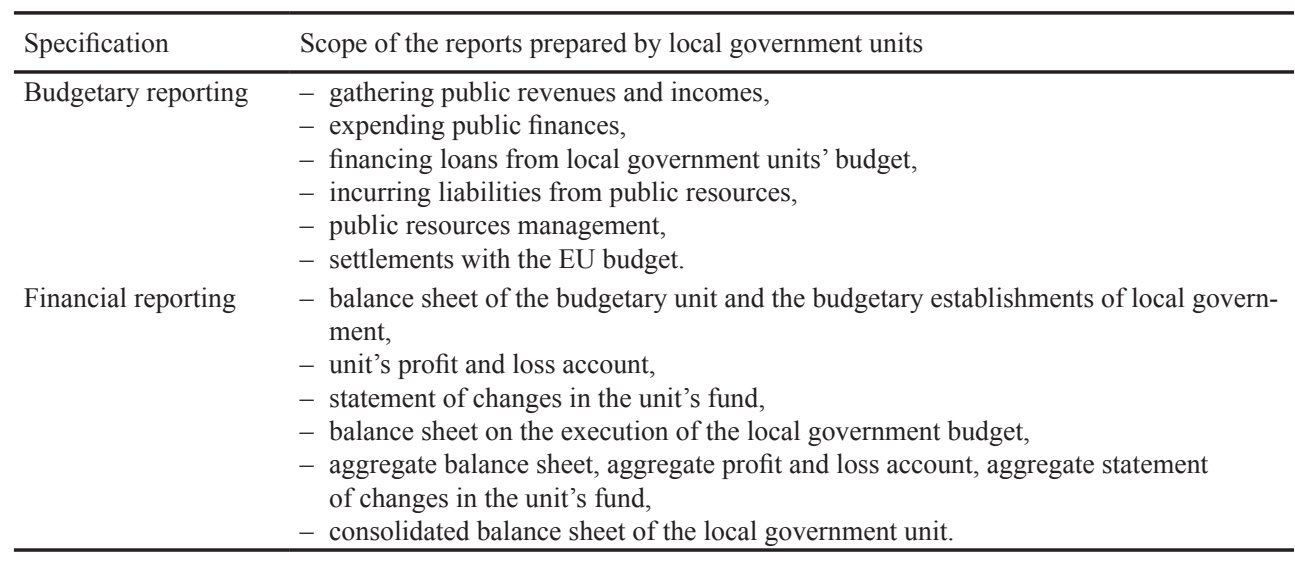

Source: own elaboration on the basis of Zysnarska (2014), pp. 182, 191.

Budgetary reports provide information on the execution of a budget that constitutes the basis for the financial economy of a local government unit. Financial reports, thus, provide information on the material and financial status, formation of the financial results and changes in a local government unit's fund. Local governments give the priority to budgetary reporting because it gives information on the achieved revenues and incurred 
expenses. Financial reporting is marginalized and the information it provides is used to a small extent to improve the financial management of local government units. What is the reason for marginalizing financial statements, which are defined as the basic component of accounting, by local government units? The reasons of such an approach lay in the definition of "budgetary accounting".

\section{Table 2}

Budgetary accounting - definition

\begin{tabular}{ll}
\hline Author of the definition & Definition of budgetary accounting \\
\hline Sikora M. & Uniform system of economic register adjusted to the needs of public administration. \\
Nowak E. (ed.) & $\begin{array}{l}\text { Accounting of the government, local government and budgetary institutions which } \\
\text { aim at providing information on the execution of a budget, and also financial plans and } \\
\text { material status of the budgetary units and other organizational and legal forms of the } \\
\text { public finances sector. }\end{array}$ \\
& $\begin{array}{l}\text { System of numeric reflection, expressed in monetary units, of the processes related } \\
\text { with the execution of a budget. It aims mainly at providing figures necessary to analy- } \\
\text { ze and control execution of the budget and guarantee the application of the budgetary } \\
\text { resources. }\end{array}$ \\
\hline
\end{tabular}

Source: Winiarska, Kaczurak-Kozak (2013), pp. 47-48.

The above presented definitions emphasize the importance of budgetary accounting in providing information on the execution of the budgets of local government units.

Another problem related with both the financial and budgetary reporting in local government units is that they are incomprehensible for recipients who are not familiar with the specificity of the financial economy of public finances sector. It is necessary to bear in mind that the information on the financial status of the specific unit of the local government shall be comprehensible for all members of the specific local government community as they make it. Due to that it seems crucial to look for the solutions that will present the current situation of the local government unit not only by means of financial data which is incomprehensible for the majority of a community residing in the area. The local community expects to be given information on the actions undertaken for their benefit and on the results of such actions.

According to A. Kamela-Sowińska, "accounting defined as a system of financial registering and reporting that functioned from its beginning until the 80 . of the $20^{\text {th }}$ century (...), will be replaced with financial economic specification within the next 50 years (...). Accounting will be losing its present nature and it will be developing into a study of universal economic specification, where numbers are replaced with descriptive accounting" (Kamela-Sowińska 2015, p. 989).

Taking the above into account, social accounting covers a wide range of issues, for example we can distinguish a micro-social economy that deals with measuring, evaluating and communicating social aspects of the organization's activities. It develops the traditional 
financial and managerial accounting into new fields: employees, residents and their environment (Dobija 2008, pp. 347, 348).

At present organizations need to operate fast and in constantly and radically changing conditions. Very often it is not economically reasonable to go back to the solutions that only recently have been effective in terms of management, as they may bring more loss to the organization than profit. It all results in the search for new knowledge, new potential of energy, negotiating goals, new criteria, processes and results and changes of concept that must be done in accordance with social responsibility. That is the origin of corporate social responsibility (Karmańska 2010, p. 3).

\section{Subject matter of the corporate social responsibility in local government units}

In October 2011, the European Commission proposed to define social responsibility as: responsibility of the companies or their influence in the society" what signifies that companies shall integrate social, environmental and ethical issues and also those related with human rights and consumer issues with their operations and the main strategy, together with all the said parties in order to:

- create mutual values for the owners, shareholders and other parties and the society as one whole, at the maximum level possible,

- identify, prevent and moderate the possible negative effects (European Commission Communication to the European Parliament, 2011).

Corporate Social Responsibility is also very important in the public sector, especially that the main task of this organization is to provide services for the local community. We need to remember that services which provide local government for members of society are usually free, that is the way profit is and is not an issue for the organization of the public sector. The biggest problem of the public sector in Poland and in another countries is the old style of management - bureaucracy. This model of classic management, which was created by $\mathrm{M}$. Weber, assumed that an organization should be ideal. Organization in bureaucracy should be perfectly rational, but it is only a model which simplifies this world. Bureaucracy in this wrong definition means a lot of documents and problems with the quality of service in the public sector (Koźmiński, Piotrowski, 2007, p. 652).

An increasing number of global leaders in government and in industry now realize that it is no longer possible to function in the management styles of the past. In an effort to close the gap extant between professed institutional morality and the implementation of ethical standards a new policy has emerged (Mc Nabb, King, Peterson 2010, p. 22).

Also in Poland we can observe changes in the public sector - new style of management - New Public Management. Nowadays we look at the public sector in a different way; we try to close the style of management to a private company. A motto of activity in public service is efficiency but not economic which means maximize profits but a rationalization 
of debts. The rules of functioning in public organizations referred to earlier, are different than in private companies. In the public sector efficiency should mean efficient use of the funds and good quality of service provided for the community.

Another premise of CSR is that business organisations have a responsibility towards various groups in society (internal and external stakeholders, employees, customers, non - governmental organizations, public authorities) and not just the owners or shareholders. For companies in the public sector this is very important as they are founded on the idea of pursuing collective interests available to everybody, everywhere, and at affordable prices. Thus common elements of public service obligation are social equality, universality, continuity, quality, affordability, user and consumer protection. For this reason, public service obligation have per se an ethical commitment, and public service companies seeking a CSR strategy seem to defend values which are very close to them (Ates, Buttgen 2011, p. 348).

Corporate Social Responsibility must be comprehensive, and secondly must be genuine as in impact - management strategy at the core of the business. To address these issues and to ensure that the full potential of CSR is realized it is important to look to more established bodies of literature for guidance and potential assimilation. Indeed, there are many obvious parallels between the development of CSR and development quality management as both a theoretical concept and management tool and clear synergies that can be derived.

CSR could be a natural progression for those organisations that have already begun their "quality journey". This concept of the quality journey (Dale, Lascelles 1997) is portrayed as having an overall element of continuous improvement where organisations both develop and use quality management in an increasingly complex and sophisticated manner, in many respects progressing from quality assurance (Hazlett, McAdam, Murray 2007, pp. 671, 672).

\section{Corporate Social Responsibility reporting in local government units}

The question is of how to report CSR in local government units? Creation of the social responsibility system shall constitute the basis for preparing reports. Specific areas of social responsibility deal with the specific activities aimed at the execution of assumptions of the unit's social responsibility. The Office of the Marshall of the Mazowieckie Voivodeship in Warsaw is an example of a unit that implemented the social responsibility system. The system is compliant with ISO 2600. It consists of the following areas that execute its assumptions:

- organization management,

- human rights,

- work practice,

- environment,

- clear operations' practice,

- consumer issues,

- engagement and development of the society. 
Each stated area of the Office has been assigned activities that will fulfil the assumptions of social responsibility. Moreover, they have also been equipped with a descriptive specification of activities. However, they lack tools to measure the level of execution of the tasks. It is the constant supervision over the effects of the performed actions that constitute the basis for searching new possibilities of developing the quality of services provided by local government units. It provides the specific local community with information on the tasks being accomplished in an easy and descriptive manner.

Table 3 below presents activities performed in the Office of the Marshall as a part of social responsibility in terms of human rights. Based in this area, Table 4 presents indicators that are helpful at social responsibility reporting and a comparison of the results at time.

Table 3

Human rights

\begin{tabular}{lll}
\hline Field & Activities & Description of activities \\
\hline $\begin{array}{l}\text { Undertaking activities for the benefit } \\
\text { of weaker groups }\end{array}$ & $\begin{array}{l}\text { Appointing representatives to deal with cooperation with } \\
\text { groups that are endangered with being marginalized }\end{array}$ \\
\cline { 2 - 2 } $\begin{array}{l}\text { Assistance in entering into the labour } \\
\text { market }\end{array}$ & $\begin{array}{l}\text { Organizing professional apprentices and internships that } \\
\text { give the possibility to gain professional experience in the } \\
\text { labour market }\end{array}$ \\
$\begin{array}{l}\text { Guaranteed access to full and reliable } \\
\text { information }\end{array}$ & $\begin{array}{l}\text { Giving additional information, preparing instructions, veri- } \\
\text { fying documents before final filing }\end{array}$ \\
$\begin{array}{l}\text { Promotion of equal treatment practice, } \\
\text { introduction of principles of equal chances } \\
\text { and no discrimination }\end{array}$ & $\begin{array}{l}\text { Equal treatment of the potential petitioners } \\
\text { Guaranteeing employees work in a friendly } \\
\text { atmosphere, with all respect to equality and } \\
\text { dignity }\end{array}$ & $\begin{array}{l}\text { Access to equal information, professional development, } \\
\text { equal access to training, reliable periodic evaluation of em- } \\
\text { ployees, clear and comprehensible division of tasks, and } \\
\text { a fair workload }\end{array}$ \\
$\begin{array}{l}\text { Active participation in actions that are } \\
\text { aimed at helping }\end{array}$ & $\begin{array}{l}\text { - collecting goods for flood victims } \\
\text { - collecting gifts for victims of the Caucasian conflict }\end{array}$ \\
\hline
\end{tabular}

Source: own elaboration on the basis of the social responsibility system of the Office of the Marshal of the Mazowieckie Voivodeship in Warsaw.

Data included in Table 3 made it possible to create examples of indicators that will allow for evaluating the level of performance of the specific activities and comparing them at time. Apart from the descriptive presentation of activities executed in the specific areas, it also will be possible to assess the effectiveness of their performance by comparing with the results from previous years.

The examples of indicators presented in Table 4, as already mentioned, will allow for an evaluation of the achieved results. They present the specific unit not only by means of just numbers, but also from a wider view. 
Table 4

Human rights - examples of indicators

\begin{tabular}{|c|c|c|}
\hline Field & Activities & Examples of indicators \\
\hline \multirow{6}{*}{ 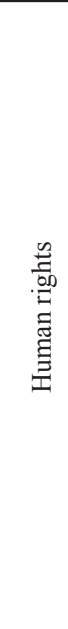 } & $\begin{array}{l}\text { Undertaking activities for the benefit } \\
\text { of weaker groups }\end{array}$ & $\begin{array}{l}\text { Reporting the effects of conducted activities by the repre- } \\
\text { sentatives - number of activities that succeeded }\end{array}$ \\
\hline & $\begin{array}{l}\text { Assistance in entering into the labour } \\
\text { market }\end{array}$ & $\begin{array}{l}\text { - number of organized professional apprentices and } \\
\text { internships } \\
\text { - control of the effects of the conducted activities - number } \\
\text { of persons who were hired after an apprenticeship or in- } \\
\text { ternship }\end{array}$ \\
\hline & $\begin{array}{l}\text { Guaranteed access to full and reliable } \\
\text { information }\end{array}$ & $\begin{array}{l}\text { - number of elaborated manuals } \\
\text { - number of documents verified before filing them }\end{array}$ \\
\hline & $\begin{array}{l}\text { Promotion of equal treatment practice, in- } \\
\text { troduction of principles of equal chances } \\
\text { and no discrimination }\end{array}$ & $\begin{array}{l}\text { Conducting period examinations, by means of surveys, } \\
\text { aimed at the evaluation of activities related with the promo- } \\
\text { tion of equal treatment }\end{array}$ \\
\hline & $\begin{array}{l}\text { Guaranteeing employees work in } \\
\text { a friendly atmosphere, with all respect } \\
\text { toequality and dignity }\end{array}$ & $\begin{array}{l}\text { - number of training sessions per one employee } \\
\text { - conducting period examinations aimed at the evaluation } \\
\text { of access to uniform information, professional develop- } \\
\text { ment, etc. }\end{array}$ \\
\hline & $\begin{array}{l}\text { Active participation in actions that are } \\
\text { aimed at helping }\end{array}$ & $\begin{array}{l}\text { - number/value of the collected goods } \\
\text { - number of persons who were helped }\end{array}$ \\
\hline
\end{tabular}

Source: own elaboration on the basis of data included in Table 3.

\section{Conclusions}

Social responsibility reporting shall play a significant role in local government units, as they aim at providing high quality services for a given society and care about society's good. Unfortunately, traditional financial and budgetary statements do not present the activities performed in specific areas and their effects.

Thanks to completing traditional financial and budgetary statements in local government units with social responsibility reports (parts related with social and environmental factors) it is possible to give insight into the full size of their operations, not only the financial ones, but also the immaterial ones.

\section{References}

Ates Z., Buttgen M. (2011). Corporate social responsibility in the public service sector: towards a sustainability balanced scorecard for local public enterprises. $\operatorname{Zog} U, 34,3$.

Dobija M. (2008). Rachunkowość zarządcza i controlling. Warszawa: Wydawnictwo Naukowe PWN.

Directive of the European Parliament and Board - 22 October 2014 (2014/95/UE) constituting amendment of the directive 2013/34/UE on revealing non-financial information and information on the diversity by some large units and groups [L 330/1, 2014].

Hazlett S-A, McAdam R., Murray L. (2007). From quality management to social responsible organizations: the case for CSR, International Journal of Quality \& Reliability Management, $24,7$. 
Winiarska K., Kaczurak-Kozak M. (2013). Rachunkowość budżetowa. Warszawa: Oficyna Wolters Kluwer Business.

Kamela-Sowińska A. (2015). Tajemnica przedsiębiorstwa a dyrektywa Unii Europejskiej o ujawnianiu informacji niefinansowych. Zeszyty Naukowe Uniwersytetu Szczecińskiego nr 854. Finanse, Rynki Finansowe, Ubezpieczenia, 73 .

Karmańska A. (2010). Zmiany w rachunkowości. In: E. Mączyńska, Z. Messner (eds.), Zagrożenia w działalności gospodarczej a prawo bilansowe. Warszawa: PTE, SKwP.

Koźmiński A.K., Piotrowski W. (2007). Management. Theory and practice. Warszawa: Wydawnictwo Naukowe PWN.

Mc Nabb D.E., King G.J., Petersons A. (2010). The evolution of public trust and social responsibility in the Baltics. EBS Review, 27.

Social responsibility in the Office of Marshall of the Mazowieckie Voivodship.

Zysnarska A. (2014). Rachunkowość budżetu, jednostek budżetowych i samorzadowych zakładów budżetowych. Gdańsk: ODDK.

\section{RAPORTOWANIE SPOLECZNEJ ODPOWIEDZIALNOŚCI BIZNESU W JEDNOSTKACH SAMORZĄDU TERYTORIALNEGO}

Streszczenie: $\mathrm{Cel}$ - próba przedstawienia możliwości raportowania odpowiedzialności społecznej biznesu w jednostkach samorządu terytorialnego.

Metodologia badania - W opracowaniu wykorzystano metodologię badań literaturowych oraz studium przypadku. Fragmenty systemu społecznej odpowiedzialności opracowane przez Urząd Marszałkowski Województwa Mazowieckiego w Warszawie zostały wykorzystane do przedstawienia zasad przygotowania raportu odpowiedzialności społecznej biznesu.

Wynik - Przeprowadzone badania pozwoliły przedstawić rolę odpowiedzialności społecznej w jednostkach samorządu terytorialnego oraz wskazać jego wpływ na ocenę efektów ich funkcjonowania.

Oryginalność/wartość - Wnioski z przeprowadzonych wskazują, że raportowanie odpowiedzialności społecznej w jednostkach samorządu terytorialnego pozwala na budowanie potencjału instytucjonalnego oraz ocenę efektów ich funkcjonowania.

Słowa kluczowe: jednostki samorządu terytorialnego, społeczna odpowiedzialność biznesu, sprawozdawczość jednostek samorządu terytorialnego

\section{Citation}

Kowalczyk M. (2016). Corporate Social Responsibility Reporting in Local Government Units. Finanse, Rynki Finansowe, Ubezpieczenia, 4 (82/1), 729-736. DOI: 10.18276/frfu.2016.4.82/1-61. 